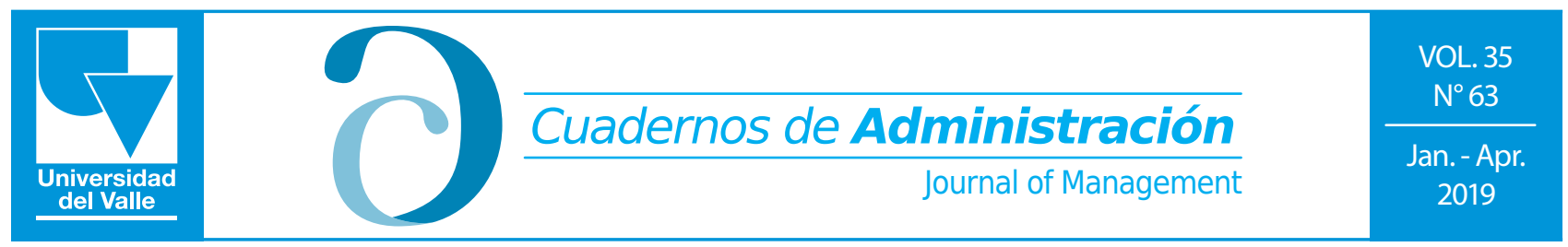

Print ISSN: 0120-4645 / E-ISSN: 2256-5078 / Short name: cuad.adm. / Pages: 70-88

Faculty if Administration Sciences / Universidad del Valle / Cali - Colombia

\title{
Real Returns of Private Pension Funds in Colombia
}

\author{
Retornos reales de los Fondos Privados de Pensiones en Colombia \\ Rendements réels des caisses de retraite privées en Colombie
}

\begin{abstract}
Flor Esther Salazar Guatibonza*
Professor, Faculty of Economics, Universidad Nacional de Colombia, Bogotá Colombia

ORCID ID: https://orcid.org/0000-0002-3415-2737. e-mail: fesalazarg@unal.edu.co
\end{abstract}

Article of Scientific and Technological Research, PUBLINDEX-COLCIENCIAS classification

Submitted: 31/01/2018

Reviewed: 30/11/2018

Accepted: 14/12/2018

Core topic: Public Policy

JEL classification: J32, G23 M20

DOI: https://doi.org/10.25100/cdea.v35i63.6139

\begin{abstract}
On the performance of the private pensions system in Colombia, Individual Savings Regime with Solidarity - RAls (per its acronym in Spanish), the results are often highlighted in terms of profitability; a thesis upheld by the fund Managers industry. In order to evaluate how significant the real returns generated by this scheme have actually been, from a database of daily transactions by the pension funds from 1995 to December 2016, and using the methodology established by the Superintendencia Financiera de Colombia (SFC-Financial Superintendence of Colombia) for the calculation of returns, was determined the net return on explicit administration costs to be borne by the members and inflation adjustment. Such endeavor found that for the moderate, fund since they began operating, their actual profitability from the perspective of their affiliates has been close to zero, as has been the trend for conservative and higher risk funds, which in recent years tended to become negative. Based on these results, we discuss the benefits that are usually attributed to individual capitalization systems in terms of high returns, better pensions, and savings protection, which contrast with the low pensions, or impossibility attaining one, that is starting to become evident in private pension funds in Colombia.
\end{abstract}

Keywords: Individual capitalization, Real returns, Pensions, social security.

\section{Resumen}

Sobre el desempeño del sistema privado de pensiones en Colombia, Régimen de Ahorro Individual con solidaridad RAls, se suele resaltar los resultados en términos de rentabilidad, tesis defendida por la industria de Administradoras de fondos. Con el objetivo de evaluar qué tan significativos han sido los rendimientos generados por este esquema en términos reales, a partir de base de datos de movimientos diarios de los fondos de pensiones desde 1995 hasta diciembre de 2016 y usando la metodología establecida por la Superintendencia Financiera de Colombia (SFC) para el cálculo de rentabilidades, se determina la rentabilidad neta de costos de administración explícitos que debe asumir el afiliado y de ajuste por inflación. A partir del ejercicio realizado se encuentra que para el fondo moderado desde el inicio de operación de estos fondos la rentabilidad real desde la perspectiva del afiliado ha sido cercana a cero, igual ha sido la tendencia para los fondos conservador y de mayor riesgo que en los últimos años tienden a tornarse negativas. A partir de los resultados se discute sobre los beneficios que suelen atribuirse a los sistemas de capitalización individual en términos de altos retornos, mejores pensiones y protección de ahorros, que contrastan con las bajas pensiones 0 
imposibilidad de pensión que se empieza a hacer evidente en los fondos de pensiones privados en Colombia.

Palabras clave: Capitalización individual, Retornos reales, Pensiones, seguridad social.

\section{Résumé}

Sur la performance du système de retraite privé en Colombie, Régimen de Ahorro Individual con solidaridad - RAl (Plan d'épargne individuel solidaire), les résultats sont généralement mis en évidence en termes de rentabilité, une thèse soutenue par l'industrie de la gestion de fonds. Afin d'évaluer l'importance réelle des rendements générés par ce régime, à partir d'une base de données des mouvements quotidiens des fonds de pension de 1995 à décembre 2016 et en utilisant la méthodologie établie par la Surintendance des Finances de Colombie, pour calculer les rendements, on détermine la rentabilité nette des coûts administratifs explicites à assumer par la filiale et l'ajustement pour inflation. Depuis le début de l'exploitation de ces fonds, la rentabilité réelle du point de vue de la société affiliée a été proche de zéro, de même que celle des fonds conservateurs et plus risqués qui, ces dernières années, ont eu tendance à devenir négatifs. Sur la base des résultats, nous discutons des avantages habituellement attribués aux systèmes de capitalisation individuelle en termes de rendement élevé, de meilleures pensions et de protection de l'épargne, qui contrastent avec les faibles pensions ou l'impossibilité de pension qui commence à se manifester dans les fonds de pension privés en Colombie.

Mots-clés: Capitalisation individuelle, Rendements réels, Retraites, Sécurité sociale.

\section{Introduction}

Within the arguments that allude to the advantages of social security systems, concerning pensions, based on individual capitalization, schemes introduced mainly in Latin America during the period of structural reforms in the 1990s, it is established that these offer the possibility of adequate pension benefits while making it possible to increase savings with the investment returns generated in financial markets. The capitalization ideology insists that while affiliates bear some administration costs, high returns will favor substitution rates and thus better retirement conditions.
The literature that refers to the benefits of this type of system sustains that individual capitalization can generate better benefits to its affiliates, compensating for the impact of aging versus defined benefits systems "if the net returns provided by funded pension schemes-that is, returns on investments net of administrative expenses and after being adjusted for differences in risk-exceed the natural rate of economic growth. In a steady state, this rate is equal to the rate of growth in wages and approximates the internal rate of return that can be paid by the payas-you-go pension schemes being replaced by reforms." (Bebczuck and Musalem, 2009, p. 83).

In contrast to what has been proposed in favor of this type of system, which has been evident in its performance and is becoming evident in the Colombian case, there are very low replacement rates that tend not to exceed $30 \%-35 \%$, as can be corroborated in the statistical information provided by the Organization for the Economic Cooperation and Development's reports (OECD) $)^{1}$ on the pension fund market. In this context, concerns arise as to whether the rates of return offered by these schemes are really high and why do these not appear in the substitution rates received by their affliates.

In the Colombian case, despite the limitations that have begun to arise in private funds' scheme to generate adequate pensions, advocates tend to exalt the results in terms of the returns obtained. However, the information on returns disclosed by the pension funds and by the entity in charge of supervising and controlling, that is, the SFC, is drawn up in nominal terms and smoothed over 36-months periods for the conservative fund, 48 months for the moderate fund and 60 months for the higher-risk fund, according to categorization of funds by risk level.

In this regard, any analysis undertaken requires taking into account not only returns in nominal terms but in real terms. It is the real returns that allow comparing

\footnotetext{
Annual series of Pension Markets in Focus. The OECD, through its reports Pension Markets in Focus, has made an effort to disclose the real returns of pension funds to its member countries, thereby seeking some degree of comparability between countries on the performance of pension funds. Likewise, the 2016 OECD Core Principles of Private Pension Regulation seeks to provide governments, regulators and supervisors around the world with a common benchmark and high-level guidance on the design and operation of private pension systems. Regarding performance assessment, it asserts "pension funds and pension institutions must evaluate their performance against benchmarks that are clear and objective and reflect their investment policy. Both gross and net investment performance should be assessed against investment targets. All costs related to investment management must be measured and informed" (e.g. 39).
} 
the financial performance of private funds at the international level, while from the perspective of the affiliates it allows finding out what is the increase in the purchasing capacity of all the resources they have set as pension savings. Nominal values do not say much about the funds' behavior because they do not take into account aspects such as inflation, risk, or costs that must be borne by those who contribute to these funds and had they not been transferred to intermediaries, they would have been part of the savings and capitalized therewith. As stated by Hinz, Rudolph, and Yermo (2010), most Latin American countries report gross cost returns, while some OECD countries report them net of some charges (e.g. administrative charges) (p. 32). Additionally, in Colombia, there is overlapping profitability (rolling average over 36 months depending on the type of fund) that smoothes the performance of yields over time.

On the theoretical and factual evidence on the high costs involved in the management of this type of pension systems, existing both internationally and for the Colombian case, concerns are raised about whether investment returns actually compensate for the charges assumed by the affiliates and whether they are also providing protection to savers against the risk of inflation, which erodes the purchasing power of any kind of savings.

A positive real return for any affiliate attempting to build pension benefits over the long term means not only having an indicator of growth of the fund but that such growth has managed to offset the costs incurred for resources that did not enter the fund for costs (as is the case with commissions, which are deducted from the contributions made) and that, in addition, this growth will be able to buy more or at least the same current amount of goods.

In this sense, this document presents the results of an exercise that sought to calculate the ex-post real returns generated by private pension funds in Colombia, that is, net returns of explicit costs ${ }^{2}$ assumed by affiliates in the stage of accumulation and inflation. For the calculations, a database of the SFC was used with information on the daily valuation of pension funds involving flow through income and expenditure from 1995 to 2016. In order to show the difference between nominal returns that are public and calculated actual returns, the same methodology established by the SFC was used to disclose quarterly returns through the estimation of internal return rates (IRR) of daily fund flows. The results address the implications that this has in the low replacement rates common for these types of systems to exhibit and question the possibility of them offering a pension with adequate pension benefits for the Colombian case, as well as their capacity as a retirement system.

\section{Real returns and their relevance}

\section{to assesing benefits generated to} system members

Pension savings are conceived as made in order to guarantee an income at the time of retirement in such a way as to provide protection during old age. Nevertheless, the income that the affiliate eventually receives from any pension scheme in the long term is subject to a series of risks that according to Bodie (1990) may be related to: (1) inadequate substitution rates that do not allow to maintain the same standards of living after retirement, (2) longevity, (3) risk investment: the possibility that the amount saved to retire is inadequate due to low investment returns, (4) inflation risk: inflation erodes the purchasing power of retirement savings, (5), the risk of cuts in benefit plans before affiliates reaches attain their pension (p.31).

In the case of individual capitalization pension schemes, from a purely financial standpoint, retirement income is a function of the contributions, of the management positions involved and, fundamentally, of the investment returns realized (Hyde, Dixon, and Drover, 2006; Hyde and Dixon, 2010). Likewise, performance has implications for the financial well-being of affiliates regarding the protection of retirement income (Tapia and Yermo 2008). "It is the financial performance that determines the relationship between the

\footnotetext{
2 Explicit costs are taken to the extent that implicit costs, referred to in the literature as shadow costs, hidden and in the Colombian regulation "Admissible costs", are difficult to identify because they are not disclosed, nor are they captured in a discriminatory manner in the information of the daily transactions funds (format 136) reported to the Superintendencia financiera de Colombia.
} 
deposits of individuals in personal retirement accounts and the annuities that can be paid at retirement" (Feldstein and Liebman, 2002, p. 2294). Therefore, to the extent that "savers invest their savings for long periods of time, often for several decades, small deviations in yield are greatly magnified as yields combine over the decades. Current performance assessment methods are too short-sighted and overlook persistence in performance, for example, the role of time" (Mitchel, Maurer, and Orzag, 2016, p.73)

To the extent that pensions under individual capitalization systems with defined contributions are backed by accumulated assets, "the arguments for private management of public pension funds are clear. If pension funds are to be invested in private assets, private management will ensure that investment is based on economic criteria. If, in addition, there is competition between privately managed funds, investment returns will be maximized, subject to regulatory restrictions on risk tasking." (Hemming, 1998, p. 21).

The expected return of this type of systems is one of the variables that has been regarded within the arguments in favor thereof and under which they have usually attributed the ability to cope with the conditions of population aging as an advantage over pay as you go pension schemes. Capitalization is considered to be isolated from demographic behavior; however, this does not guarantee a system with a greater capacity to increase private savings in the long term. Some analysts suggested that the returns of individual accounts, even when risk-adjusted, would be much higher by up to three to five times the returns of a public pension system (Genetski, 2004 , p. 313). This argument of achieving higher rates of return that, along with others, was used to justify the introduction of individual capitalization, assumes that in a dynamically efficient economy financial profitability is always higher than the rate of economic growth (Ferreiro and Serrano, 2011, p. 317). As stated by Willmore (1999), "contributions to a pension scheme represent savings (sacrificed consumption), regardless of whether the funds are invested or not, and workers naturally would like these savings to grow at the highest possible riskadjusted return. Privatization with individual funded accounts promises to achieve this automatically" (p. 10).

However, while profitability directly impacts pension benefits, and it is the one capable of providing some actual protection against inflation, for example, it is an important risk source to be borne by affiliates. Real returns understood as returns that are assumed adjusted by some factors, such as inflation, management costs, risk, among others, are important inputs that together with replacement rates generated by the system allow to analyze the efficiency and benefits that these types of schemes are generating for the building of savings for the retirement.

The administration costs of pension funds are justified as the remuneration to the handling that generates favorable returns for participants as the result of investment activities. The issue that has begun to be documented is that private funds are characterized by high costs and low rates of real return. The higher the charges, the lower the net contributions invested, and therefore the lower the fund's maturity value and the larger the reduction in yield (Blake, $2006 b$ p. 125). In this way, costs have a direct impact on the net income earned for pension funds and thus on pension benefits for old-age income protection. In individual capitalization systems, "accumulating adequate savings requires high returns and low fees" (Tapia and Yermo, 2008, p. 2).

Administrative costs have a substantial negative effect on the pension benefits eventually earned by affiliates. This has been analyzed by the literature and generally coincides with the importance of their magnitude and effect (Diamond, 1996, 1997, 2000; Murthi, Orzag, and Orszag, 1999; Whitehouse, 2001; Mitchell, 1998). "Geanakoplos, Michell, and Zeldes (1998) show that when the rates of return on individual capitalization funds are corrected by considering the costs of privatization of the system, management costs, and increased portfolio risk, the rates of return of the public pension system and individual capitalization systems are virtually the same" (Quoted in Moreno and Ortiz, 2010 p.171). In turn, Singh (1996) shows in detail why reforms have not had the expected effects on 
deepening financial markets, accumulation and growth. Some theoretical perspectives analyze these low returns as a result of the lack of competence and concentration of the pension managers industry (Srinivas and Yermo, 1997).

Profitability and risk in these schemes allude both to their sustainability and to the responsibility of the State to guarantee citizens' pension rights. The original belief tends to overestimate the ability of individual accounts to guarantee pension benefits, and difficulties have become apparent with the maturation of the systems that introduced these schemes. Likewise, it is not so true that these systems are immune to variables such as demographic aging. As asserted by Ferreiro and Serrano (2011), "in the context of population aging, as repeatedly pointed out (Brooks, 2002; Geanakoplos, Magill and Quenzii; Takáts 2010), the profitability of financial (and actual) assets is negatively affected. Therefore, the changing of the model is not justified by the demographic issue, but by the micro-and macro-economic advantages of funded pension systems over the public pension systems" (p. 318, own translation) that have been assumed. Some studies suggest that economically adverse outcomes, such as poor performance, should be seen as an inherent feature of a private-enterprise system that is permeated with bare and unrestricted self-interest, regardless of the costs to others. And the costs are considerable, as the relentless pursuit of pecuniary advantages results in a profound economic and social disadvantage (Hyde and Borzutzky, 2016).

Likewise, to the extent that the savings in pension plans and the very achievement of the pension product carry a fairly long period of time, requires more attention to the risk faced by members in terms of the deterioration of the purchasing power of their savings, especially considering that the purpose of a pension plan is to provide adequate income after retirement and precisely to prevent the deterioration of the quality of life of the aging population. For this reason, inflation is a very important variable at the time of retirement, it is the reflection of changes in costs or living standards over time and pension annuities are usually indexed to inflation in order to protect people from a change in price levels. To this extent, this is a parameter that has a significant effect on the cost or capital necessary to finance a pension if private funds are involved.

As stated by Barr and Diamond (2006), from the perspective of the individual, the goal of pensions is to allow people to continue consuming after they have stopped working. Pensioners are not interested in money, but in consumption: food, clothes, heating, medical services, that is, consumption of goods produced in the corresponding time, and therefore, by younger workers. This is why lower rates of return or higher prices end up denying the consumption those retirees expected (Barr and Diamond, 2006)

Inflation is also a risk to pensions and in terms of transparency, its effect on individual accounts must be revealed. Without knowledge of actual returns, savers cannot assess how their pension savings will maintain their purchasing capacity in the future. This is why the OECD has focused on real returns instead of nominal returns. Funds reserved by affiliates in the present are only worth what they can buy at tomorrow's prices. Only if returns on savings exceed the increase in price levels will the standard of living that these savings can provide in retirement be maintained.

In this sense, if pension savings have the function of guaranteeing future income at the time of retiring and therefore maintaining adequate living conditions, savers need to know not only how much their savings have grown considering the costs they have incurred, which has meant sacrificing current consumption, but also how much it has grown above the increase in prices in the economy.

Therein lies the importance of also disclosing net inflation rates of return to affiliates, inasmuch as if these fall below inflation, their savings will be losing the ability to buy the same amount of today's goods and services in the future. Likewise, in the stage of accrual the growth of investment must be such that at the time of retirement, in a private scheme, by incorporating the increases on account of inflation of annuities, the capital can be covered in order to acquire 


\begin{tabular}{|c|c|c|c|c|c|}
\hline \multirow{2}{*}{ Country } & \multicolumn{2}{|c|}{10 -year average } & \multirow{2}{*}{ Country } & \multirow{2}{*}{$\begin{array}{c}\text { 10-year average } \\
\text { Nominal }\end{array}$} & \multirow[b]{2}{*}{ Real } \\
\hline & Nominal & Real & & & \\
\hline Iceland & 6.9 & 1.2 & United States & 2.2 & 0.4 \\
\hline Australia (1) & 6.2 & 3.4 & Luxembourg & 3.0 & 1.1 \\
\hline United Kingdom & 7.3 & 4.7 & Austria & 2.6 & 0.6 \\
\hline Canada & 5.9 & 4.2 & Slovenia & .. &.. \\
\hline Netherlands & 5.5 & 3.8 & Italy (4) & 3.2 & 1.6 \\
\hline Denmark & 5.8 & 4.0 & Korea & 3.8 & 1.3 \\
\hline Belgium & 5.1 & 3.2 & Portugal & 3.2 & 1.8 \\
\hline Mexico (2) & 6.5 & 2.4 & Greece & .. & .. \\
\hline Chile & 6.8 & 3.0 & Latvia & 3.0 & -0.7 \\
\hline Turkey (2) & 10.7 & 2.3 & Estonia (5) & 1.0 & -2.2 \\
\hline Norway & 5.5 & 3.4 & Slovak Republic & .. & .. \\
\hline Israel (3) & 5.6 & 3.7 & Czech Republic & 2.1 & 0.1 \\
\hline Spain & .. & .. & & & \\
\hline
\end{tabular}

the life annuity. According to this, if inflation has not been compensated or barely covered during the accrual period, a savings system like this ends up generating no return for affiliates.

These individual capitalization models advocate the sovereignty of affiliates and their ability to plan their pension savings with the help of the market, where they are able to choose managers to act in their capacity, who are supposed to be efficient in generating the best performance and results for the investment of their funds. Nevertheless, even assuming market and management efficiency, it is highly relevant for affiliates to have transparent information regarding assets allocation indicators and in particular on returns and costs incurred by the investment. International evidence on these schemes suggests that "management charges are imposed in ways that diminish their visibility, impairing the possibility of consumer sovereignty-specifically, where charges are deducted from pre-tax earnings or from each plan participant's account balance" (Hyde and Borzutzky, 2016, p. 74).

At the international level, a concern has been made known about the decline in returns of private pension funds. Particularly, the OECD has been interested in the disclosure of actual returns in order to achieve comparability between countries. In the case of the United States, some analyses show that beneficiaries of defined contribution plans have generated fewer returns than profit schemes defined with a differential between $0.6 \%$ and $1.4 \%$ annually between 1990 and 2012. The factors estimated to explain this behavior include operating costs resulting from the transaction costs of individual capitalization schemes (Schwartz and Cagnati, 2017, p. 4). Some reports generated by the OECD (Pension Funds on figures) found, for instance, that the average profitability for these countries in the period December 2014-December 2015 was 0.4 and for the United States it was $-1.7 \%$. In the Table 1, the OECD has determined the average actual return on funds over the past 10 years, although in some cases they are only inflation-adjusted and not necessarily net of administration costs.

\section{Private pension funds in Colombia}

Within the framework of structural reforms in Latin America in the 1990s, in Colombia, in 1993, Act 100 adopted a dual pension system consisting of two different schemes that compete with each other: the Average Premium Regime (with defined benefit) -RPM (by its acronym in Spanish)- and the Individual benefit plans (with defined contributions) -RAIS by its acronym in Spanish)-. In the 
Figure 1. Composition of mandatory pension funds by type of fund (as of December 2017)

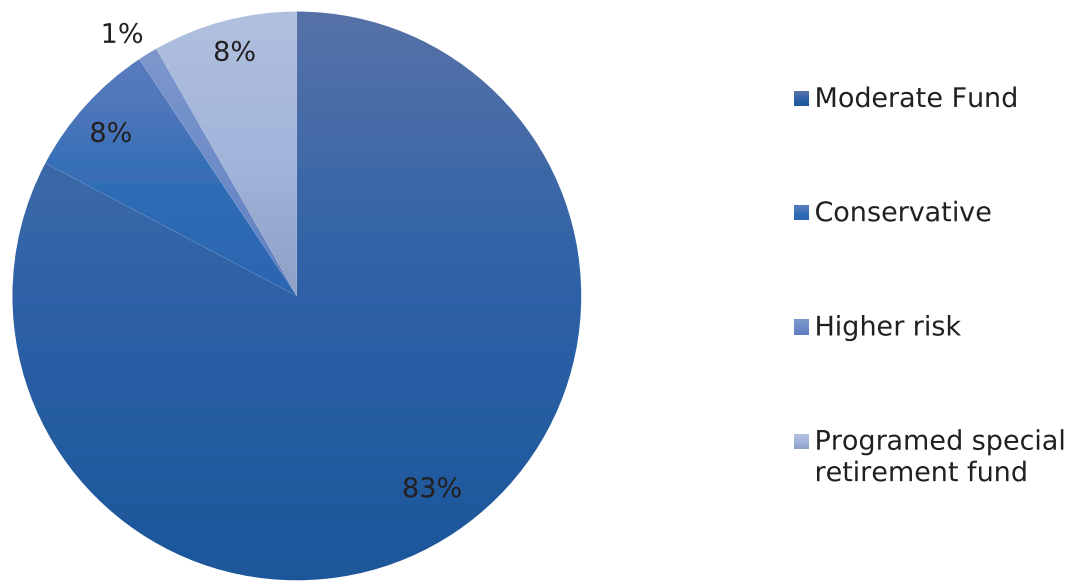

Source: Authors' own elaboration from statistical data SFC-pension statistics.

first one, the contributions of the affiliates and their returns constitute a common public-nature fund, which guarantees the payment of pensioners' benefits, which is currently administered by Colpensiones. The individual capitalization savings scheme is characterized by the fact that the pension conditions will depend on the capital accrual realized by the person. The worker has an individual account consisting of monthly contributions and returns obtained from the administration of the investment portfolio to the charge of a Pension Fund Administrator (AFP by its acronym in Spanish), on the latter scheme is that performance has been discussed in terms of the actual returns generated for its affiliates.

In 2009, Act 1328 established the creation of the multi-funds concept for private pension funds, which were introduced in 1993. Multifunds establish a differentiation of funds according to the level of risk assumed in the investments of the same, seeking to achieve higher levels of profitability when exposed to greater risk, especially in the case of young affiliates. According to this Act, there are three types of funds; the aggressive one, for younger workers, with a portfolio of equity investments allowed up to $70 \%$, and the rest in other deeds such as Term Deposits (CDT by its acronym in Spanish) and Government Bonds (TES by its acronym in Spanish). The Moderate, for people between 35 and 45 years old, made up of shares up to $40 \%$ of equities. Finally, the Conservative, which can only be allocated up to $20 \%$ to equities, since it will be for people between 55 and 60 years old (Salazar, 2010, p. 420).

The largest share of funds remains in the moderate fund, around $83 \%$ of reserves, $8 \%$ in the conservative one, in the highest-risk fund $1 \%$ of funds administered by the funds and about $8 \%$ in the programmed retirement fund (which corresponds to a fund not in the accrual stage but of those who have opted for this mode of retirement), according to Figure 1 as of October 2017.

Regarding portfolio structuring, nearly $40 \%$ of the funds are invested in public debt, $11 \%$ in local fixed income, $17 \%$ in local equities and around $24 \%$ in foreign equities.

This trend usually matches what happens with most pension funds, according to the OECD (2015) pension market report, pension funds in the OECD in 2014 were invested at $23.8 \%$ in equity instruments, and $51.3 \%$ in bonds and debt instruments. Pension funds in non-OECD countries present a similar situation, $27.3 \%$ and $51.9 \%$, respectively. They only find that six countries report investment funds at more than $50 \%$ in equity. (OECD, 2015, p.14). The same report states that the existence of management costs reduces nominal returns, which combined with high inflation in the case of some countries lead to negative actual returns. 
In the Colombian case, the disclosed returns are nominal, which are reported by the SFC without taking into account the effects of commissions, insurance and other charges borne by the affiliate as well as the adjustments for inflation. The disclosure of profitability is done quarterly and monthly with the calculation of the minimum profitability. Although there is this reporting periodicity, profitability is calculated for the last 36, 48 and 60 months for conservative, moderate and higher risk funds respectively. No returns are reported for shorter periods. The compulsory pension fund existing before the entry into force of the multi-fund scheme was constituted as the moderate fund type since March 2011.

Based on this information disclosed, there is a tendency to assert that funds have reached annual returns above $8 \%$, however, nominal returns do not permit to affirm whether the performance of funds has actually been positive for affiliates, particularly if we refer to nominal returns accrued since the funds started operating, which carries the effects of the high price levels in the early 1990s (from the starting of the funds until 1998 there was an average annual inflation of $19.61 \%$ ). Likewise, it is necessary to consider the costs incurred by affiliates and their effect on their savings, since the result is positive in any investment system only if the returns exceed the costs that have been assumed on the same. Figures $2 \mathrm{a}, 2 \mathrm{~b}$ and $2 \mathrm{c}$ show the trend of nominal returns that are disclosed by the Financial Superintendence of Colombia.

According to this, the calculation of real returns will follow, net of explicit costs, to be analyzed against the nominal returns that have been reported historically concerning the performance of pension funds since their introduction through Act 100 of 1993.

Figure 2a. Effective annual accrued return moderate pension fund*
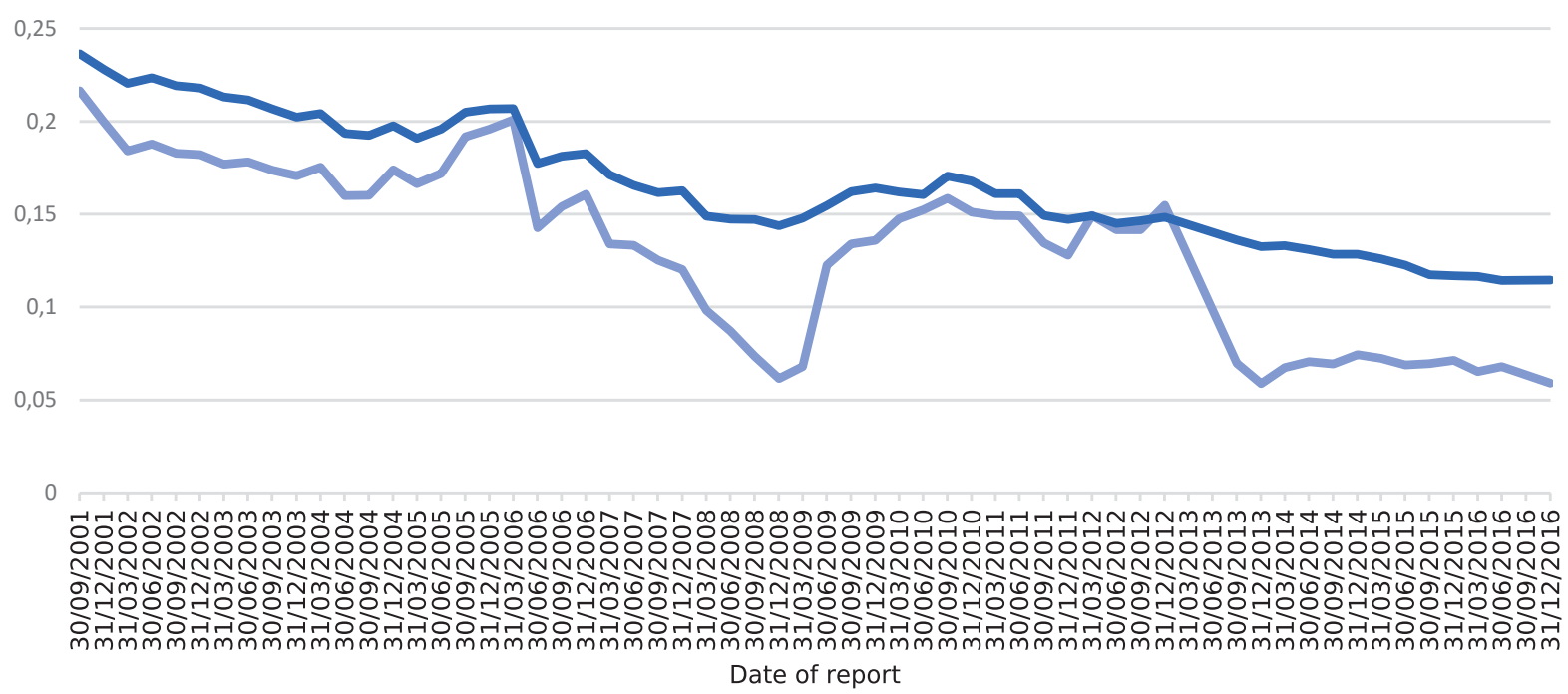

Effective annual accrued profitability -period Since the starting of the system in May 1994

Effective annual accrued profitability - period

since the starting of the system in May 1994. 
Figure 2b. Effective annual Accrued return conservative pension fund (moving period 36 months*)

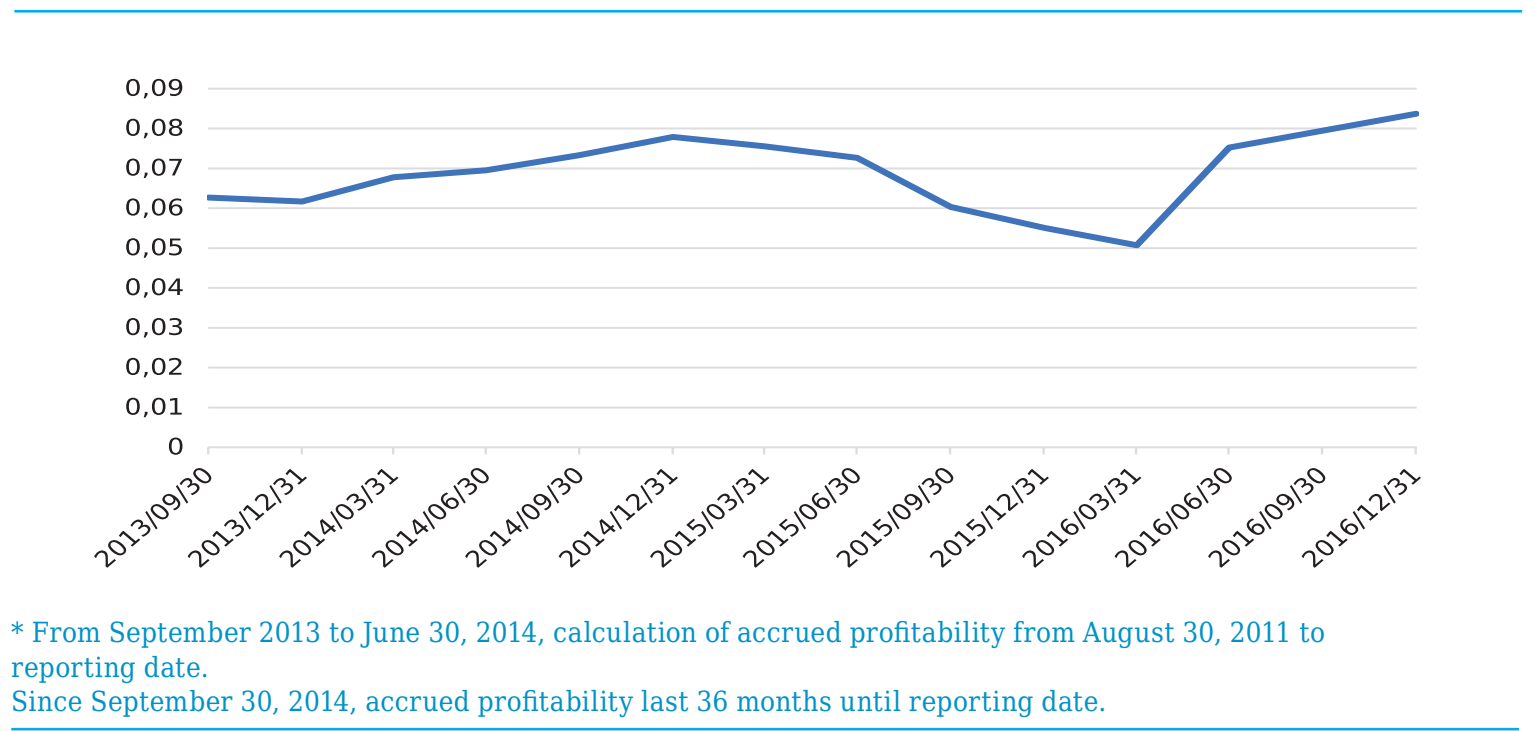

Source: Author own elaboration database Superintendencia Financiera de Colombia.

Figure 2c. Effective annual accrued return higher-risk pension fund (moving period 60 months*)

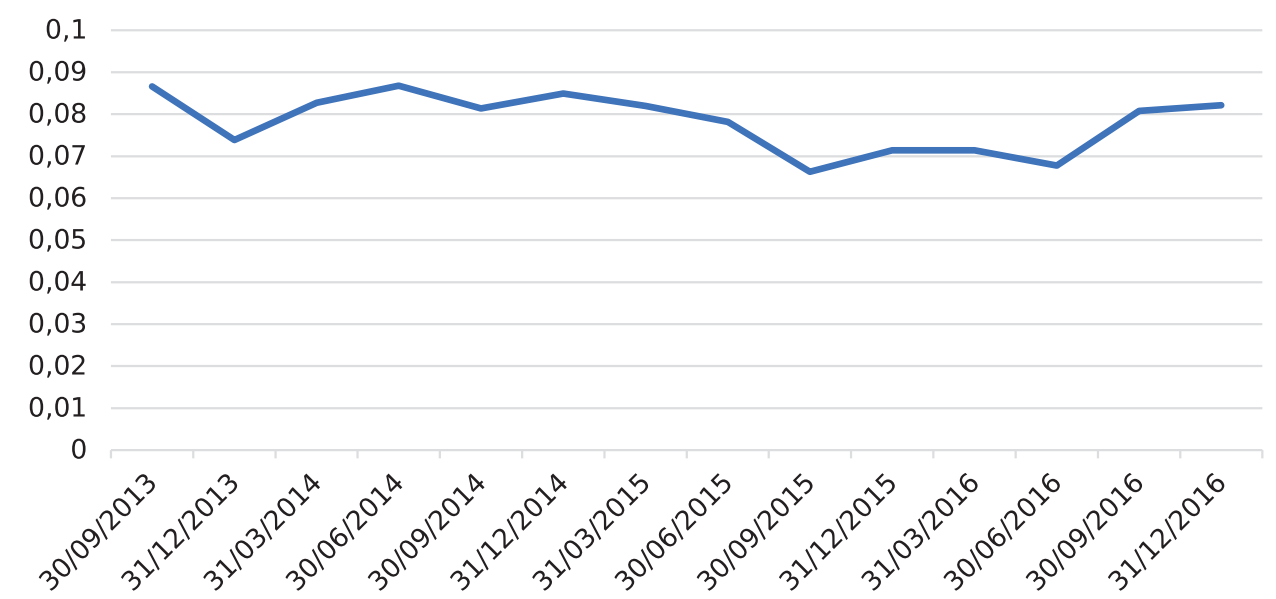

* From September 2013 to June 30, 2016, calculation of cumulative profitability from August 30, 2011 to reporting date.

Since September 30, 2016, accrued profitability last 36 months until reporting date.

Source: Author own elaboration database Superintendencia Financiera de Colombia.

\section{Calculation of real returns generated by private pension funds}

\subsection{Methodology and source of information}

There are two ways in which the ex-post returns of a fund can be measured: through time-weighted rates of return (geometric averages) and rates of return calculated as internal rates of return (IRR).

The time-weighted cumulative rate of return on investments in a fund does not take into account the effect of cash inflows 
and outflows within the fund. This is why the calculation through internal rates of return is one of the customary methods used in the case of pension funds to the extent that it controls the flows of the fund (contributions, withdrawals, transfers, etc.); the disadvantage of this is that it requires the fund to be valued whenever there is a cash flow and may be greater than the calculation through time weighted returns, depending on how flows occur. In the Colombian case, the methodology established by the SFC makes use of the daily valuation of the fund with its respective net flows (income minus expenses). This information is taken back to determine the real returns generated (Base of the daily movement of funds 19952016) by applying the internal rate of return methodology defined by the SFC.

Given the availability of information on the daily movement of the funds, based on the determination of profitability by internal rates of return, the reduction in returns resulting from including in daily fund flows, administration costs, termination fees, transfer fees, social insurance for disability and survivors and contributions to the minimum pension guarantee fund, that is, the "IRR" net of explicit charges for the participant is obtained.

This rate makes it possible to compare the nominal return that is disclosed by the regulator, SFC, and the actual yield, which considers the contributions made by the affiliates, which are deducted from his contributions, and on generated returns in the case of the commission of the unemployed. The inclusion of these charges in the determination of the daily flows for the calculation of the IRR conceives that the higher the costs assumed by affiliates, the lower the share of their contribution invested, therefore, it comes forward as the reduction of the actual return obtained from resources destined for pension savings. This measure of the "net IRR" allows expressing the loss for affiliates as a result of the charges that they must bear as the difference between the gross contribution and the actual contribution that is applied to his savings fund.

As pointed out above, the methodology established by the SFC detailed in Chapter
12 of accounting and financial circular ${ }^{3}$, in terms of how pensions funds are assessed and the estimation of their profitability, makes for the figures to be comparable with public nominal rates disclosed by this entity.

Paragraph 1.1.3 of the aforementioned chapter, on pension funds, states:

In the case of compulsory pension funds, on the value of each portfolio at the end of day $t$, before returns (VFC), the value of each type of fund at the end of day $t$, including returns (VFCR), is obtained by applying the income and expenses inherent to each of them.

VFCR $=$ Value of the type of fund or portfolio at the end of day t including returns, i.e. value at the start of operations on day $t+1$

$\mathrm{VFC}=$ Value of the fund type or portfolio at the end of day $t-$ before returns

INGt $=$ Income of the type of fund or portfolio on day $\mathrm{t}$

GTSt $=$ Expenditure of the type of fund or portfolio on day $\mathrm{t}$

Income (ING): The financial returns generated by the assets that make up the type of fund or portfolio, such as profits in investment valuation, returns on repo, simultaneous and temporary transfer of securities, profit in the valuation of spot transactions and profit in the valuation of derivatives. In the case of profit or loss in investment valuation, it should be noted that the profit or loss must be that originating on the basis of the reference prices or rates and margins, as provided for in Chapter I of this Circular, published on t. Income on the sale of assets, Income from cancellation of contributions, any other income in favor of the type of fund or portfolio

Expenditure (GTS): For the compulsorytype of pension funds, those established in the Legal Circular, Title IV, Chapter II, paragraph 2.1.

Likewise, in terms of determining the profitability generated by private pension funds, the following is laid out:

Daily profitability. The calculation of the 
annual actual daily return (RD) obtained by the type of fund or portfolio should be made according to the following formula:

$=\left\{\left(\frac{\text { Returns credited a day }}{\text { Value of the fund at the start of operations }}\right)+1\right\}^{365}-1$

Cumulative profitability of the type of fund or portfolio. It is the Internal Rate of Return, in annual terms, of the daily cash flow of the calculation period, which considers as income the value of the type of fund or portfolio at the start of operations on the first day of that period (VFI) and the net value of the daily contributions made during the calculation period and as outflow the value of the type of fund or portfolio at the end of the last day of the calculation period including returns (VFCR).

"Net value of daily contributions" means the amount derived from deducting from resources received the amount of the withdrawals or transfers made during the day. (Value of the type of fund or portfolio at the end of the day before yields, minus the value of the type of fund or portfolio at the start of operations).

The calculation period for the funds of compulsory pension is that of the last thirtysix (36) months, for the types of conservative and special scheduled retirement fund; of the last forty-eight (48) months, for the moderate fund and of the last sixty (60) months for the highest-risk fund

For the purposes of determining returns generated by private funds net of charges, the following are taken into account within the daily net flows:

- The administrative commission that is deducted from the contributions made by the affiliates: The authorized value for this fee is $3 \%$ on the income basis of contribution, including the contribution to social insurance for disability and survivors. As of July 2017 , the average of this was $1.29 \%$ and social security insurance $1.71 \%$. These two concepts about the contribution made are equivalent to $18.75 \%$ thereof. It takes into account what is paid for pension insurance to the extent that, although it is not part of what is called commission for administration costs, it is a payment that the affiliates must mandatorily make to the insurance company and these are resources that do not enter their capitalization account, therefore it is an additional cost that they must bear in the system.

- A commission charged on balances in periods of absence (in which the affiliate does not make contributions), the Managers deduct an amount not higher than $4.5 \%$ from the returns paid during the month to the individual account.

- Transfer fee: This is a type of commission applicable when transfers occur between schemes or administrators and from or to alternative pension schemes. It corresponds to $1 \%$ on the last income basis of contribution. Decree 656 of 1994, article 39- Ministerio de Hacienda y Crédito Público (Ministry of Finance and Public Credit).

- Contributions to the minimum pension guarantee fund (FGPM per its acronym in Spanish), although not an administrative cost, are a charge that affiliates must bear within the scheme as a solidarity mechanism to guarantee a pension to those who do not meet pension requirements and do not have sufficient capital. This charge corresponds to $1.5 \%$ of the base contribution income, which is $9.375 \%$ of the contribution made by the affiliate. This contribution was implemented under Act 797 of 2003 and as of January 1, 2004, the percentage indicated as a solidarity mechanism has been allocated.

Although the so-called admissible costs that occur in the operation of the funds and that are charged within the expenses of the funds should also be considered, given the opacity of the costs and that in the same structure of income and expenses considered for the determination of the daily values of the funds and their capture format (136) are not discriminated, hence the commonly given name of hidden costs or shadow costs, it was not possible to include their dimension 
for the current exercise and therefore refers only to explicit costs. Concerning transparency, this is an aspect that should be particularly informed by the funds and supervisory body (SFC) and be one of the aspects to discriminate in the format of daily movement of funds.

Likewise, these commission-net returns are adjusted for inflation in order to obtain estimates of the actual returns net of explicit charges generated for the different types of funds. Taking into account that profitability is presented as annualized cumulative, inflation is likewise taken for the corresponding period or window of observation.

The exercise is performed from the daily data of:

- Value of the fund at the beginning and end of the period with and without yields.

- Financial returns paid.

- Commissions involved.

- Payment of social security insurance.

- Contributions to the Minimum Pension Guarantee Fund

According to the methodology used for the presentation and reporting of profitability by funds authorized by the SFC, the net value of explicit charges is calculated in such a way that the real effect of the returns on the accrual of pension balances becomes clear.

Although the costs of administration fees, insurance and minimum pension guarantee are incurred not on the funds but on the contributions, reckoning them within the net flows makes it possible to assess the extent to which the profitability obtained returns those amounts which affiliates cease to accrue in their individual account as a result of the Administration.

The methodology for determining returns of private funds established within the regulation of the same and described above takes into account the concept of internal rate of return (IRR), which is obtained in consideration of the flows of contributions, commissions, other daily income and expenses and the final savings accrued that are present in the funds for the calculation period considered, what is done is to obtain the net internal rate of return of the costs involved for the affiliates. For the purposes of comparability with nominal returns, the rolling calculation periods used by the SFC are preserved and this internal rate of return is annualized.The Net IRR is of interest as a type of return that allows us to analyze how wealth or savings destined for retirement have changed. For the purposes of obtaining real returns, the results of the "net IRR" are adjusted with inflation data for the period considered in the calculation.

Analytical calculations of cost-net returns raise questions about whether profitability is obtained on accumulated resources, while cost is obtained as taxable income on contributions, termed in the literature as misalignment between the cycle of profit in profitability and the cycle of costs. From some perspectives, the existence of a prepaid effect is discussed to the extent that commissions are prepaid since the contribution will be administered for the remainder of the contributory life until the time of pension. However, at the aggregate level throughout the life of contributions, these commissions will be constant, having a prepaid effect at the end of the contribution stage does not imply these will be lower. In order for such a prepaid effect to be considered, it would be necessary for the fees on the flow to be lowered over time, as the retirement age approaches. Likewise, to the extent that the calculations are made in an aggregate way regardless of the type of affiliate or individual balances, it is possible to assume the collection of commissions on flows, because in the financial year, the IRR is obtained on the flows generated in the movement of funds, then it is possible that the cost of commissions are considered as a further flow within the calculation of the internal rate of return.

The administration fees are proportional on the flow and the internal rate of returns is determined based on the flows of funds, then it is considered as a negative effect on flows and therefore it is possible to determine the effect it generates on accumulation and the 
return obtained considering that the returns are generated in the period but that such charges to the affiliate were also generated in the same period.

This makes it possible to analyze the cost implied by those resources entering the account and not accruing, nor being capitalized in case they were paid. It allows us to assess how the returns generated by the system in the period are compensating those resources that in the same period are meant for the affiliates, resources allocated to the savings of their pension but that are transferred to the administrators.

Thus, the net IRR in this exercise expresses the periodic contributions made by workers and the return received by them at an aggregate level. This and the returns disclosed by the funds and the SFC are referential, the true profitability that an affiliate obtains comes from the analyzing his individual situation in terms of the resources disbursed and, lastly, the balances present in their individual account and the ability of these to finance a pension.

As pointed out above, a database with the daily movements of pension funds from 1995 to 2016 was used (1,103,014 Records). Profitability is calculated for moderate, conservative and higher-risk funds. The IRR is calculated for each period in each Pension Fund Administrator and the system average is obtained as the internal rates of return obtained by each administrator weighted by the participation weight of each administrator's fund value. In 2017 there were 4 administrators operating in the market: Old Mutual, Colfondos, Porvenir and Protección, although the composition has changed since the start of the private pension funds system in 1995.

\subsection{Results obtained}

For the moderate fund, which, as indicated above, concentrates approximately $83 \%$ of pension funds, the annual actual cumulative return disclosed by the SFC from the start of operations until 31 December $2016^{4}$, weighted average by the share in the daily balance of the fund in each administrator corresponds to $11.45 \%$. Based on the estimates made, including adjustments for explicit costs borne by affiliates, as well as the effect of inflation, the result is that as of December 31, 2016 the adjusted effective annual realized cumulative return was $0.48 \%$. Estimates and differences between nominal and adjusted rates are reflected in the Figure 3.

The real annual cumulative profitability since the start of operations is a very good indicator because it covers a period of a little more than 20 years, which is a considerable time close to the minimum that it could take someone to capitalize some savings to build some pension benefit. In nominal terms, annual average cumulative rates of over than $10 \%$ were reported, particularly because of the effect of high inflation rates up to 1998, above $16 \%$ and up to 2003 , above $6 \%$. Nonetheless, as it has been estimated, for someone who started contributing at the beginning of this private fund system, to 2016 in actual terms, means that their savings have had a return close to zero $(0$, $48 \%)$, due to the costs that he has had to bear and because the only thing that the return on investment of the same has managed is to somehow compensate for inflation.

For the different moving periods of 36 and 48 months for which the generated profitability has been presented (Figure 4), the volatility that characterizes the returns of these funds comes to light, although presenting it for periods of 3 and 4 years greatly softens the high variability. The fragility of these pension systems in the face of market conditions is evident; for example in 2007 and 2008 when the funds had significant losses, just like the trend in the decline in profitability in recent years that has made actual returns for affiliates negative since 2015. The adjusted data maintain the same trend as nominal profitability with average differences between nominal and adjusted by more than 8 percentage points that capture the effect of both inflation and explicit charges.

For this fund, we can observe the deterioration that the rates of profitability suffered for periods that count since August 2011, which in actual terms are not only close to zero but become negative as much as - $2 \%$,

Circular 11 of 24 January 2017. 
Figure 3. Real annual cumulative return moderate fund since start of operations

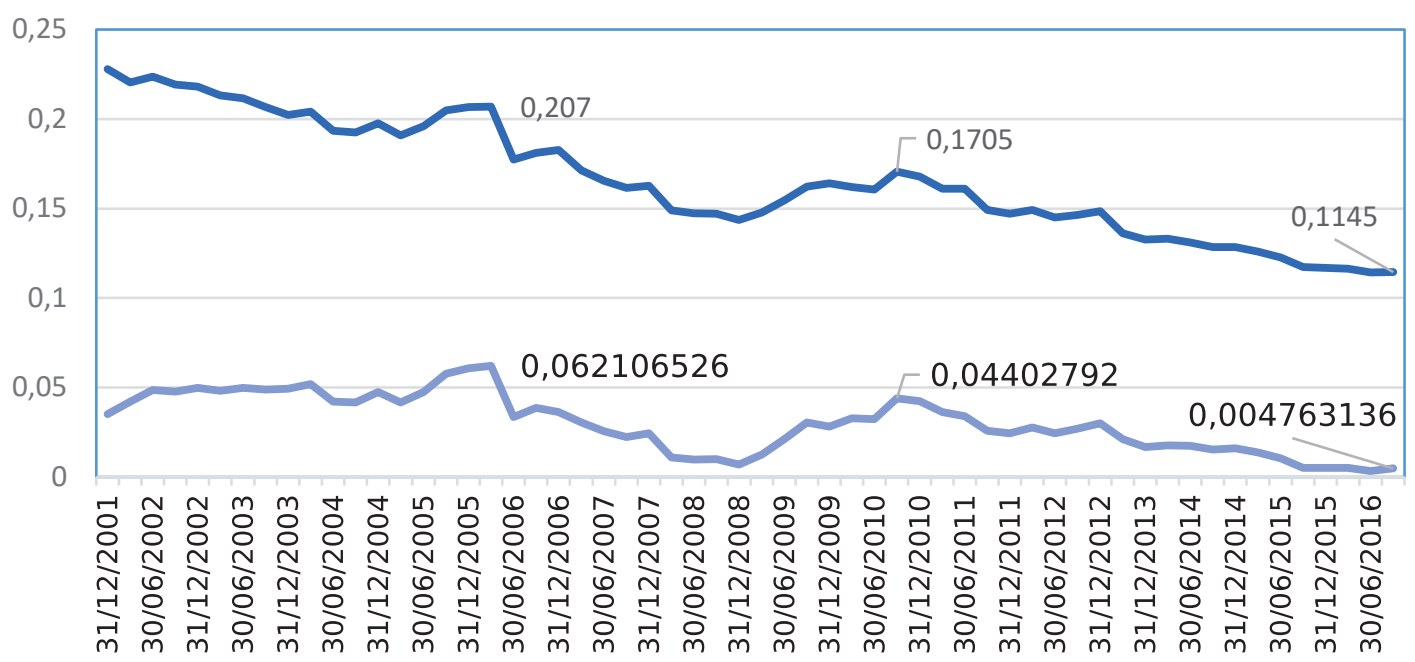

Effective annual accrued profitability

Real effective annual accrued profitability

Source: Author own elaboration database Superintendencia Financiera de Colombia

Figure 4. Real annual cumulative return moderate fund moving average periods of 36 and 48 months*

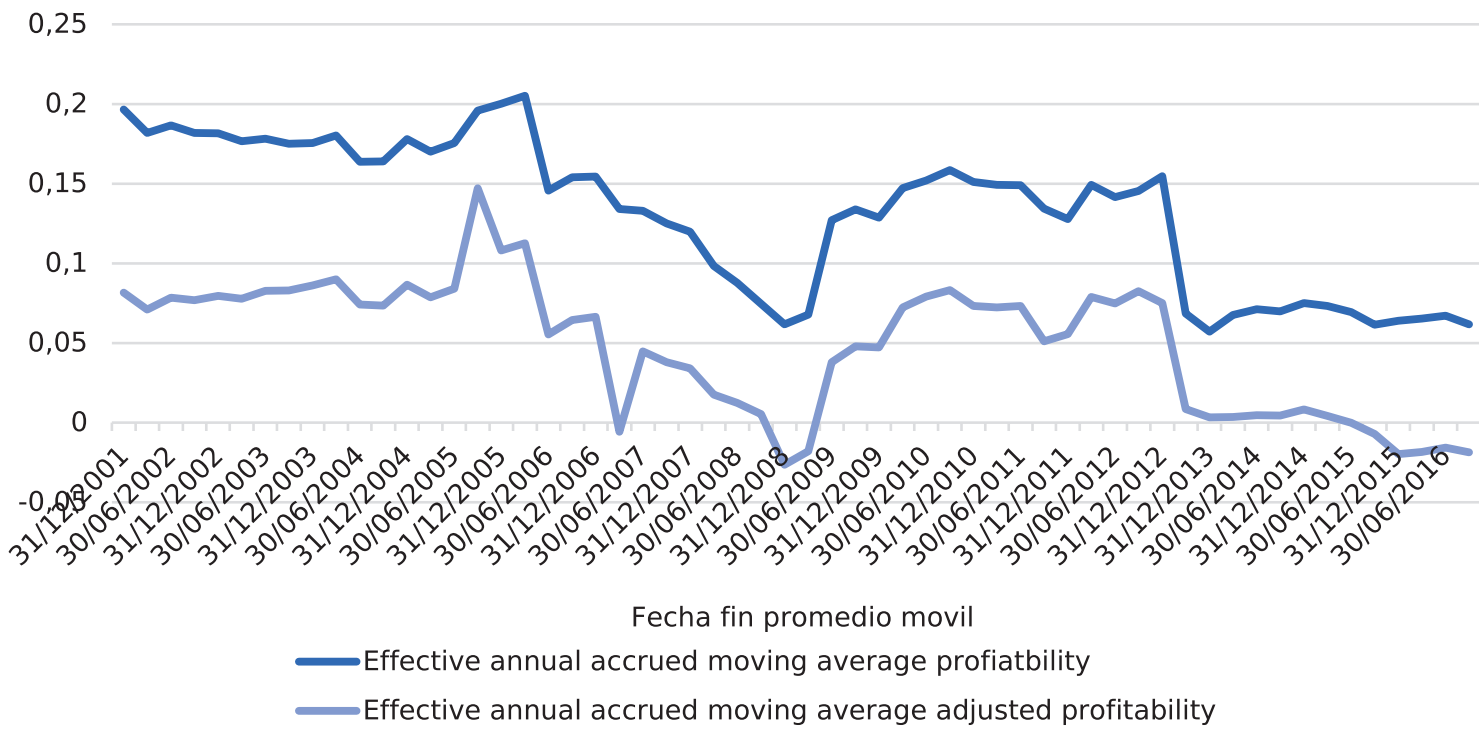

${ }^{*}$ From 1996 to June 2010 last 36 months

Since June 2010 last 48 months

Since September 2013 Moderate Fund - Period calculation from August 31, 2011 to date of calculation

Since September 2015 last 48 months 
Figure 5. Real annual cumulative return moving average (48 months) moderate fund from multi-fund inflow

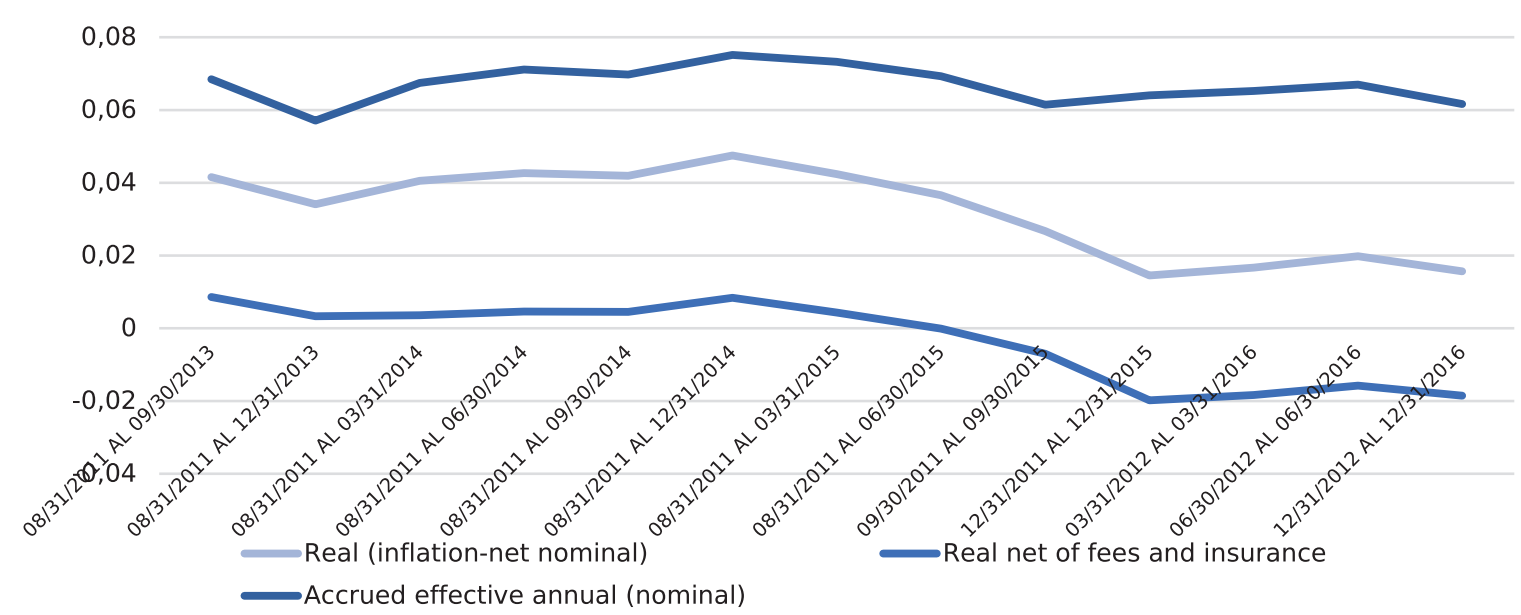

Source: Author own elaboration database Superintendencia Financiera de Colombia.

Figure 6. Annual cumulative profitability moving average (36 months) conservative fund from multi-fund inflow

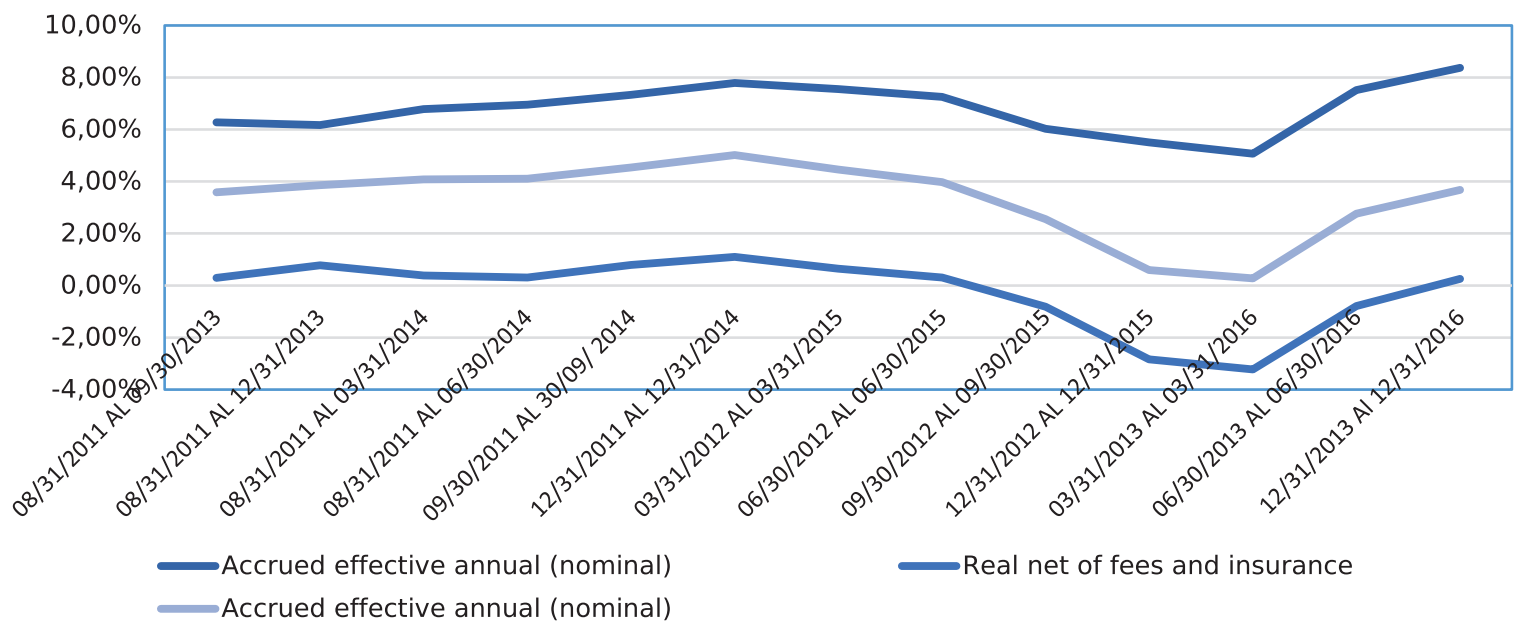

Source: Author own elaboration database Superintendencia Financiera de Colombia.

and this is precisely the period after the entry of multi-funds (Figure 5). In the case of the conservative fund, which has $8 \%$ of pension funds, the results obtained, show that in the positive periods since their entry into force, we could talk about actual returns of $1 \%$ and since 2015, as in the case of the moderate fund, they have been negative (Figure 6).

In the case of higher-risk funds, an investment scheme in which around $1 \%$ of the funds administered partake, the results obtained show positive periods with actual returns of $2 \%$ since their entry into force; however, it is necessary to take into account this type of fund exposes the savings its affiliates to a higher risk, which is why these risk-adjusted results tend to zero and have been negative since 2015 (Figure 7).

There is no benefit for the affiliates that can be attributed to the existence of differentiation of funds by risk level and actually, no type of fund exhibits positive 
Figure 7. Moving average annual cumulative return (60 months) high-risk fund from multifund inflow

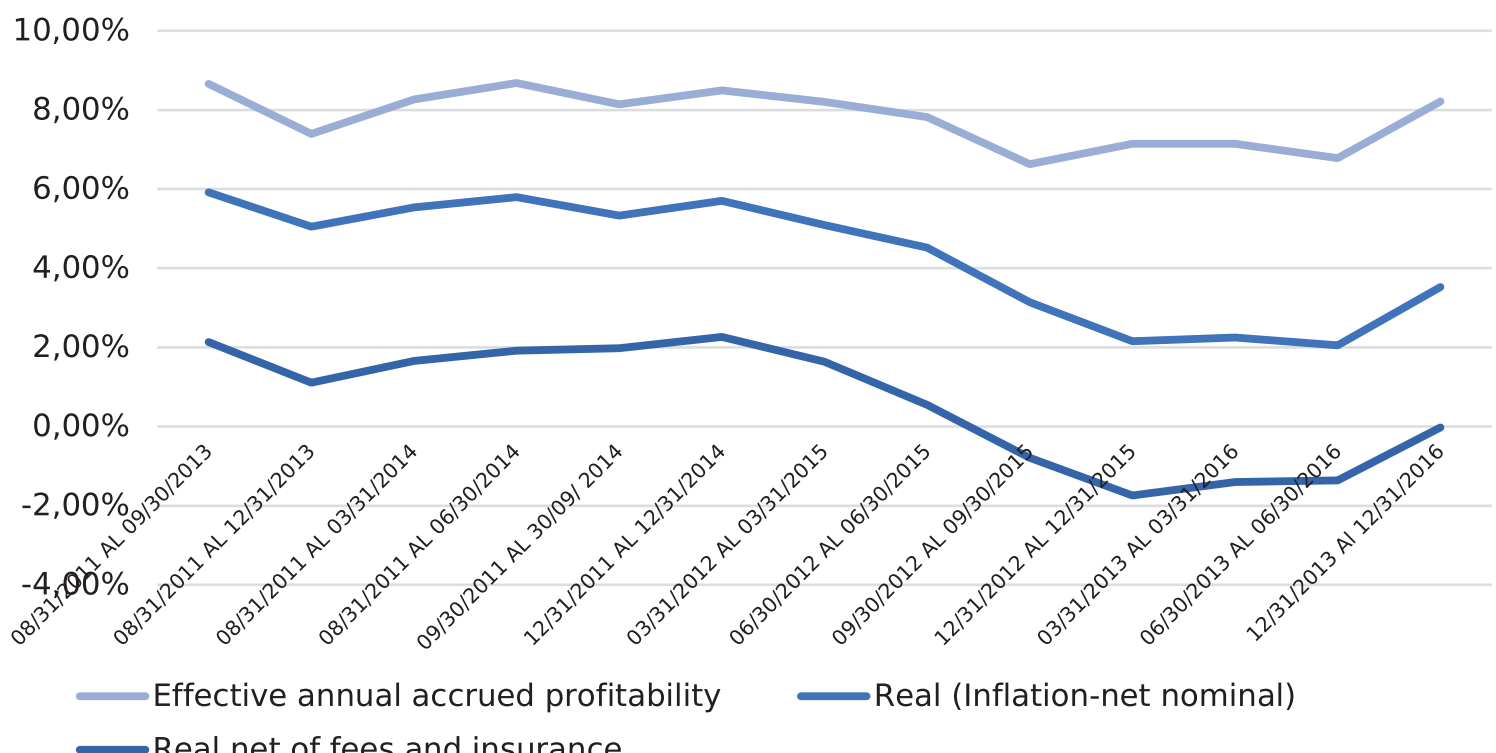

Source: Author own elaboration database Superintendencia Financiera de Colombia.

outputs capable of highlighting regarding the purpose of the existence of these funds as a social security system for pensions; this is discussed below.

\section{Discussion and Conclusions}

Evidence of the low replacement rates obtained by those who become pensioners in the private fund system in Colombia and the large share (more than 50\%) that does not accrue enough capital for a pension, as well as the insistence of the Administrators industry of high rates of return, led this exercise to evaluate the real rates of return that are being generated in this system, which do not manifest in better and adequate pensions.

Contrary to what happens in defined benefit pension schemes, which is the nature of the state-managed retirement system in Colombia administered by Colpensiones, individual capitalization does not offer individuals any guarantee that their contributions and investment returns will suffice to achieve a definite benefit of retirement, wherefore all the risk falls on the affiliates. The very-longterm investment horizons that characterize pension savings in these schemes make any kind of profit uncertain and it is not possible to expect extraordinary returns. According to Abramov, Radygina, and Chernova (2015) "maintaining a fixed risk-return ratio for a portfolio as the horizon increases, an investor needs to increase the ratio of lower-risk financial assets during the asset allocation process. This thesis becomes especially relevant in the context of retirement savings management" (p. 273). If this approach is accepted, returns on low-risk assets will not be the highest and therefore the returns generated will not be so either.

Likewise, the high administrative costs and charges imposed end up undermining the pension benefits of the affiliates of this regime and deteriorating the returns generated on the resources allocated to their pension savings. According to the exercise conducted, if profitability is considered net of costs and risks such as inflation, it becomes close to zero and negative, a situation that may be explaining, partly (there are another series of variables), why nominal returns do not appear in practice as better pensions. If we add the admissible or hidden charges, we would be saying that in reality, the private 
fund system has generated negative returns for its affiliates and society as a whole, which had to bear all the transitional costs in the reform to the system in 1993.

The exercise allows analyzing the actual profitability generated in a considerably broad period, from 1995 when this scheme was getting started until 2016, which at best could be the minimum time a person requires in order to save for a pension. For this period, the actual annual cumulative return generated by the system (moderate fund concentrating $83 \%$ of pension funds) was $0.48 \%$. This means that a person who started contributing in 1995 and has made contributions until 2016, in reality, the profitability generated has barely managed to cover the costs assumed and provide some kind of protection against inflation; yet still, the resources sacrificed in consumption and destined for pension savings in real terms has not grown.

If we were to also take into account not the adjustment in prices (inflation) as it was done, but the adjustment in living standards (wage growth), and as mentioned above, other hidden costs, 21 years of contributions would have negative actual returns. This makes it possible to affirm that in real terms the results are not those that are set forth as positive in this type of system, whose existence is justified in the ability to capitalize the savings that lead to their growth for the benefit of their members.

Likewise, if a person who has been in the system since 1995 and has obtained zero or negative actual returns wishes to opt for his or her pension, that person must bear additional costs depending on the type of pension he or she chooses. In the case of a life annuity, these costs may be above $5 \%$ plus the indexation of his or her pension annuity to the inflation at the time of retirement. So, what has been accrued is losses from mandatory saving as is the nature of pension savings. As for the meaning of indexation to inflation in the calculation of a pension, according to what Blake (2006b) established, inflation of $3 \%$ will generate annuities $30 \%$ lower than that of an annuity not indexed to inflation (p. 256). If this is taken into account, in no will way the generated profitability compensate for what the affiliate bears in costs during the accrual stage and much less will it be enough to cover the costs that will also be generated at the time of retiring. This partly explains the low replacement rates of between 20 and 30\% generated by this type of scheme.

On inflation coverage, although there is controversy among those who believe that pension benefits should be given in nominal or real terms, it is agreed that the protection from inflation offered by pension schemes is far from full and that the problem of not reckoning the effects of inflation on pension benefits leads to underestimating savings for retirement. Arnold and Auer (2015), upon reviewing studies that analyze the link between asset returns and inflation, found a long-term balance between common stocks and inflation, but in general, investments in equities, gold, fixed income securities and real estate have difficulties in protecting against inflation. In this sense, the result obtained for the profitability obtained since the starting of the system would attest to this difficulty, therefore, it cannot be expected that as the result of investments in financial markets, the capitalization schemes will generate an adequate diversification and effective protection to affiliates.

Returning to the theoretical aspects of pension social security systems mentioned at the beginning of this document, it has been formally justified that private capitalization funds, as a pension system could be superior to the public pension system insofar as they generate real cost-net returns and riskadjusted above the rate of growth of the economy or real wage growth. If we are talking about actual returns close to zero or negative, it means that such an argument of superiority is not occurring in the Colombian case either.

The low-actual-returns results obtained were expected in the context of what happens in other countries. Table one showed that for countries with highly developed capital markets such as the United States profitability in the last 10 years has been only $0.4 \%$.

On this, in particular, it is necessary to contextualize that international expectations of future returns performance are not the most optimistic, so results as different from 
those shown so far could not be expected. The difficulties experienced by the economies in recovering from the 2008 crisis present low prospects for high-interest rates as well as high mistrust towards private pension funds. "The fall in personal savings returns, especially since 2008, have undermined the credibility of personal pensions, making it extremely difficult to promote in a context of public political uncertainty and encouraging to change the mandatory provision to a voluntary one" (Whiteside, 2014, p. 79).

Expectations for future returns point to a reduction in interest rates. On expectations of low interest rates in the future, the OECD (2015) states that to the extent that companies are not investing efficiently and effectively since they would rather give money to shareholders or participate in mergers and acquisitions, for example, innovative investment and the growth in productivity needed to support the valuation of bonds and equities in the future will decrease, and for institutional investors' portfolios will generate low returns which will generate solvency issues for pension funds and insurance companies, since the valuation of liabilities will rise and lower accrued assets for retirement. The risk comes from the fact that the flow of contributions, dividends and repurchases will be invested less in real assets and more in leverage, higher riskier returns and complex products with low liquidity. (pp. 89-90)

In conclusion, the arguments outlined raise doubts about the ability of the individual capitalization private pension fund scheme to provide basic pension protection for its members. It is unlikely that these types of schemes will be the solution to the crisis of the aging population and can hardly generate adequate benefits while involving high administrative costs and profit margins for Administrators.

It is necessary to continue to research on the conditions and replacement rates with which private fund affiliates in Colombia are being pensioned in order to have more elements to discuss the real capacity of this type of schemes to provide protection for the individual and to generate some kind of benefit to society as a whole, which does not seem to be occurring thus far.

\section{References}

Abramov, A., Radygina, A., \& Chernova, M. (2015). Long-term portfolio investments: New insight into return and risk. Russian Journal of Economics, 1(3), 273-293.

Arnold, S., \& Auer, B. R. (2015). What do scientists know about inflation hedging? North American Journal of Economics and Finance 34,187-214.

Barr, N., \& Diamond, P. (2006). The economics of pensions. Oxford Review of Economic Policy, 22(1), 15-39.

Blake, D. (2006a). Pensions Economics. England, UK: John Wiley and Sons Ltda.

Blake, D. (2006b). Pension finance. London, UK: John Wiley and Sons Ltda.

Bebczuk, R., \& Musalem, A. (2009). Can the Financial Markets Generate Sustained Returns on a Large Scale? In R. Holzmann (Ed.), Aging Population, Pension Funds, and Financial Markets. Washington, USA: World Bank

Bodie, Z. (1990). Pensions as retirement income insurance. Journal of Economic Literature, 28(1), 28-49.

Diamond, P. (1996). Proposals to restructure social security. Journal of Economic Perspectives, 10, 67-88.

Diamond, P. (1997). Macroeconomic aspects of social security reform. Brookings Papers on Economic Activity, 2, 1-66.

Diamond, P. (2000). Administrative costs and equilibrium charges with individual accounts. in J. Shoven (Ed.), Administrative Aspects of Investment-Based Social Security Reform (pp. 137-162). Chicago, USA: The University of Chicago Press.

Feldstein, M. \& Liebman. J. (2002). Social Security. in J. Auerbach \& M. Feldstein (Eds.), Handbook of Public Economics (Chap. 32 Vol. 4). North Holland. Elsevier Science

Ferreiro, J., \& Serrano, F. (2011). Uncertainty and Pension Systems Reforms. Journal of Economic Issues, 45(2), 317-322.

Geanakoplos, J., Mitchell, O. S., \& Zeldes, S. P. (1998). Would a Privatized Social Security System Really Pay a Higher Rate of Return? NBER, (Working Paper 6713).

Genetski, R. (2004). Administration Costs and the Relative Efficiency of Public and Private Social Security Systems. Pp.313-332 in Social Security and its discontents: perspectives in 
choice. Edited by Michael Tanner. Washington, DC, USA: Cato Institute.

Hemming, R. (1998). Should public pension be funded? Retrieved from https://www.imf.org/ external/pubs/ft/wp/wp9835.pdf

Hinz, R., Rudolph, A., \& Yermo, J. (2010). Evaluating the Financial Performance of Pension Funds. The International Bank for Reconstruction and Development. Washington D.C., USA: The World Bank.

Hyde, M., Dixon, J., \& Drover, G. (2006). The privatisation of mandatory retirement income protection: International perspectives. Lewiston, USA: Edwin Mellen Press Ltd.

Hyde, M., \& Dixon, J. (2010). Can private pensions be trusted? A cross-national review. International Journal of Social Economics, 37(4), 276-292.

Hyde M., \& Borzutzky, S. (2016). Rent Seeking in Private Pensions. Concentration, Pricing and Performance. London, England: Palgrave Macmillan Publishers Ltd.

Ministerio de Hacienda y Crédito Público. (1994, marzo). Decreto 656 de 1994. Diario Oficial, (41.283). Bogotá. Colombia.

Mitchel, O. (1998). Administrative Costs in Public and Private Retirement Systems (pp. 403 - 456) Retrieved from https://www.nber.org/books/ feld98-1

Mitchell, O., Maurer, R., \& Orszag, M. (2016). Retirement System. Risk Management: Implications of the New Regulatory Order. Oxford Scholarship. DOI: 10.1093/ acprof:oso/9780198787372.001.0001

Moreno, A., \& Ortiz, F. (2010). Economía política de la reforma del sistema colombiano de pensiones. Revista de Economía Institucional, 12(22), 167-192.

Murthi, M., Orszag, J. M., \& Orszag, P. (1999). The charge ratio on individual accounts: lessons from the United Kingdom. Retrieved from http://www.bbk.ac.uk/ems/research/wp/1999/ PDFs/ewp9902.pdf

$\begin{array}{ccc}\text { OECD (2016). } & \begin{array}{c}\text { Core Principles of Private } \\ \text { Pension } \\ \text { from }\end{array} & \begin{array}{r}\text { Pegulation. } \\ \text { http://www.oecd.org/pensions/ }\end{array}\end{array}$

Core-Principles-Private-Pension-Regulation. pdf

OECD (2015). Business and Finance Outlook 2015. París, France: OECD Publishing.

Salazar, F. (2010). Impacto de los costos de administración y de los periodos cesantes en la construcción de beneficios pensionales de los afiliados al Régimen de Ahorro Individual en Colombia. Cuadernos de Contabilidad, 11(29), 413-443.

Singh, A. (1996). Pension reform, the stock market, capital formation and economic growth: a critical commentary on the World Bank's proposals (No. 54924). Retrieved from https:// mpra.ub.uni-munchen.de/54924/1/MPRA_ paper_54924.pdf

Srinivas, P., \& Yermo, J. (1997). Do investment regulations compromise pension fund performance? Evidence from Latin America. Revista de Análisis Económico, 14(1), 67-120.

Schwartz, J., \& Cagnati, R. (2017). Adding private markets to DC pension plan portfolios - a case study. Retrieved from https://www. partnersgroup.com/fileadmin/user upload/ Documents/Research_PDF/2017012̄3_Adding private_markets_to_DC_pension_plan_ portfolios.pdf

Superintendencia Financiera de Colombia. (2011). Circular externa Financiera 016 de 2011. Bogotá. Colombia.

Tapia, W., \& Yermo, J. (2008). Fees in Individual Account Pension Systems: A Cross-Country Comparison. OECD Working Papers on Insurance and Private Pensions, (27).

Whitehouse, E. (2001). Administrative charges for funded pensions: comparison and assessment of 13 countries. In Private pension systems: Administrative costs and Reforms (pp. 85-154). Paris, France: OECD Publications Service.

Willmore, L. (1999). Public versus Private Provision of Pensions. Retrieved from http:// dx.doi.org/10.2139/ssrn.143149

Whiteside, N. (2014). Privatization and after: time, complexity and governance in the world of funded pensions. European Review of Labour and Research, 20(1), 69-81.

\section{¿How to quote this article?}

Salazar Guatibonza, F. E. (2019). Real Returns of Private Pension Funds in Colombia. Cuadernos de Administración, 35(63), 70-88. DOI: https://doi.org/10.25100/cdea.v35i63.6139 